University of Wollongong

Research Online

Faculty of Law, Humanities and the Arts Papers (Archive)

Faculty of Arts, Social Sciences \& Humanities

$1-1-2017$

Legal personality of robots, corporations, idols and chimpanzees: a quest for legitimacy

S M. Solaiman

University of Wollongong, sheikh@uow.edu.au

Follow this and additional works at: https://ro.uow.edu.au/lhapapers

Part of the Arts and Humanities Commons, and the Law Commons

Research Online is the open access institutional repository for the University of Wollongong. For further information contact the UOW Library: research-pubs@uow.edu.au 


\title{
Legal personality of robots, corporations, idols and chimpanzees: a quest for legitimacy
}

\begin{abstract}
Robots are now associated with various aspects of our lives. These sophisticated machines have been increasingly used in different manufacturing industries and services sectors for decades. During this time, they have been a factor in causing significant harm to humans, prompting questions of liability. Industrial robots are presently regarded as products for liability purposes. In contrast, some commentators have proposed that robots be granted legal personality, with an overarching aim of exonerating the respective creators and users of these artefacts from liability. This article is concerned mainly with industrial robots that exercise some degree of self-control as programmed, though the creation of fully autonomous robots is still a long way off. The proponents of the robot's personality compare these machines generally with corporations, and sporadically with, inter alia, animals, and idols, in substantiating their arguments. This article discusses the attributes of legal personhood and the justifications for the separate personality of corporations and idols. It then demonstrates the reasons for refusal of an animal's personality. It concludes that robots are ineligible to be persons, based on the requirements of personhood.

\section{Disciplines}

Arts and Humanities | Law

\section{Publication Details}

S. M. Solaiman, 'Legal personality of robots, corporations, idols and chimpanzees: a quest for legitimacy' (2017) 25 (2) Artificial Intelligence and Law 155-179.
\end{abstract}


1 Legal Personality of Robots, Corporations, Idols and Chimpanzees:

\section{A Quest for Legitimacy}

Abstract

4 Robots are now associated with various aspects of our lives. These sophisticated 5 machines have been increasingly used in different manufacturing industries and

6 services sectors for decades. During this time, they have been a factor in causing

7 significant harm to humans, prompting questions of liability. Industrial robots are

8 presently regarded as products for liability purposes. In contrast, some commentators

9 have proposed that robots be granted legal personality, with an overarching aim of

10 exonerating the respective creators and users of these artefacts from liability. This

11 article is concerned mainly with industrial robots that exercise some degree of self-

12 control as programmed, though the creation of fully autonomous robots is still a long

13 way off. The proponents of the robot's personality compare these machines generally

14 with corporations, and sporadically with, inter alia, animals, and idols, in 15 substantiating their arguments. This article discusses the attributes of legal 16 personhood and the justifications for the separate personality of corporations and 17 idols. It then demonstrates the reasons for refusal of an animal's personality. It 18 concludes that robots are ineligible to be persons, based on the requirements of 19 personhood.

20 Keywords: Legal Personality, Robots, Corporations, Idols, Chimpanzees

21 Running Title: Legal Personality of Robots

\section{Introduction}

23 Robots have been slowly but steadily permeating our life in many respects, ranging 24 from manufacturing industries to the administration of justice. Amongst their various 
25 usages, the increase in the use of industrial robots (IRs or IR in singular) is perhaps most phenomenal. The International Federation for Robotics (IFR) in a 2015 report on IRs found an increase in the usage of robots by 29 percent in 2014, which recorded the highest sales of 229,261 units for a single year (IFR 2015). IFR estimates that about 1.3 million new IRs will be employed to work alongside humans in factories worldwide between 2015 and 2018 (IFR 2015). IFR has termed this incredible rise as 'conquering the world' by robots (IFR 2015).

Parallel to this proliferation of IRs, IFR predicts an exponential rise in service robots too, which will reach $31 \mathrm{~m}$ by 2018 (Cookson 2015). The Foundation for Responsible Robotics (FRR) identifies the areas of usage of service robots: these machines are operational in, inter alia, entertaining and taking care of children and elderly people, preparing food and cooking in restaurants, cleaning residential premises, and milking cows (Cookson 2015). There are presently a total of $12 \mathrm{~m}$ service robots employed across the globe, as reported by FRR (Cookson 2015).

The usefulness of robots is undeniable; however, what concerns us are the serious risks associated with the usage of these robots, as co-workers at work or as companions of the vulnerable in particular. This is because they have already been involved in causing numerous deaths around the world. For example, there have been a total of 26 deaths killed by robots' malfunctions in the United States (US) over the past 30 years, whilst the United Kingdom (UK) recorded 77 robot related fatal accidents in 2005 alone (Noack 2015, quoted from The Economist). A recent accident, in Frankfurt at a Volkswagen factory on 29 June 2015, was the death of a 22-year old worker at the hand of a robot, but prosecutors are still undecided as to who should be 
50 prosecuted for this tragic death (Bora 2015). Worryingly, the robotic industry itself

51 has its own share of accidents (Dhillon 1991). Even medical robots are not always

52 trustworthy: a recent study released in July 2015 reveals that surgical robots have

53 been linked to the deaths of at least 144 and injuries of 1,391 over a period of 14 years

54 (2000-2013) in the US (Alemzadeh et al. 2015). Many believe that even more harmful

55 consequences are 'lying around the corner' (Cookson 2015), and that these machines

56 are destined to take over the world (see Leenes and Lucivero 2014).

57 Despite such a distressing picture, legislators and policymakers remain largely unmoved. Robotics Professor Noel Sharkey, Chairman of FRR, asserts that it is time now to take action before robots cause further harm (Cookson 2015). Consistently, the UK Health and Safety Executive emphasises the need for adequate protection of

61 people from malfunctioning collaborative robots at work (Health and Safety

62 Executive 2012). This protection requires regulation, which generally entails ascription of liability for harm committed by humans or human-made machines.

64

65 Some academic discourse has viewed differently the need for the separate legal personhood of the possessor of artificial intelligence (PAI) such as robots for decades

67 (Pagallo2013). Therefore, a debate persists in the absence of concrete guidelines

68 about the "persons' ${ }^{1}$ to be held liable as to who should take responsibility for such harm: the manufacturer, the employer, or the machines themselves. One group of the debate argues that robots should be conferred with personality in order to exonerate

71 their makers and users from potential liability; the other group strongly opposes this

72 view. The primary basis of the proponent's arguments is an analogy between robots

73 and corporations, though robots are sporadically likened to, animals and idols as well.

\footnotetext{
${ }^{1}$ The terms 'person' or 'persons' in this article refers to 'legal personality' unless otherwise mentioned, because we omit 'moral personality' from consideration in this piece.
} 
75 This article critically examines the attributes of personality from legal points of view

76 in exclusion of moral personality ${ }^{2}$ and applies them to corporations, idols,

77 chimpanzees and robots, with a view to finding a rationale for ascribing legal

78 personality to robots. Admittedly, corporations have legal personality recognised

79 worldwide; idols' legal personality is accepted in some jurisdictions, chimpanzees'

80 personality has been denied repeatedly, whilst robots' legal personhood has not been

81 recognised as yet anywhere, to the best of our knowledge. The analysis in this article

82 relies on both judicial and scholarly interpretations of the attributes of legal

83 personality, and concludes that industrial and services robots do not meet those

84 personhood qualities, and therefore the claim for their personality is unfounded.

85

86

\section{Concept of Legal Personhood - Creation and Recognition}

87 None of the three 'human' creations being robots, idols and corporations - nor the

88

89

90

91

92

93

94

95

96

97 animal chimpanzees that are the concern of this article can be defined as a person, according to the ordinary dictionary meaning of the word, which recognises the personhood of living human beings only. None of these three are rational-creations with the capability of 'feeling' and 'willing' that would be directly comparable with that of humans, except chimpanzees which have some similarities with human beings. However, legal personhood is not necessarily synonymous with or confined to human beings (Byrn v New York City Health \& Hosp Corp 1972). When the term 'personality' comes to legal concepts, conferring this status (personality) on any entity depends upon a given jurisdiction having an independent legal system. This is why there is no uniformity across legal systems in recognising entities as a legal person

\footnotetext{
${ }^{2}$ For differences between legal and moral personality, see Blyth (1906).
} 
98 (Gray 1909). For example, some idols are legal persons in some countries such as

India, but not in others, such as the UK, and this dissimilarity exists even though both countries belong to the common law family (see Bumper Development Corp Ltd $v$ Commissioner of Police of the Metropolis 1991).

Generally, law confers certain rights and imposes specific duties on legal persons, entitles them to own and dispose of property and to sue others in their own right in order to enforce these entitlements, and permits them to be sued by others following any breach of legal duty owed to another person or to the rest of the world. A person is thus defined in law by reference to 'rights' and 'duties', which means that a legally recognised person is subject to legal rights and duties (Smith 1928, see also Gray 1909). As defined in Black's Law Dictionary, a person is a 'human being,' or 'natural person,' and '[a]n entity (such as a corporation) that is recognised by law as having the rights and duties of a human being' (see Matter of Nonhuman Rights Project, Inc v Stanley 2015/hereinafter Stanley 2015'). ${ }^{3}$ Similarly, covering both natural and artificial persons, Butterworths Australian Legal Dictionary describes a person as 'a separate legal entity, recognised by the law as having rights and obligations' that includes human beings and entities of humans only whom 'the law regards as capable of rights and duties' (Nygh 1997, citations omitted). It further clarifies, referring to Salmond, that the capability of enjoying rights and performing duties is the exclusive criterion of legal personality, and adds that any beings who possess this capability are legal persons, and conversely other beings who lack this capability are not such persons, regardless of whether the beings are human or not (Nygh 1997). Hence,

\footnotetext{
${ }^{3}$ Cited in Stanley 2015). However, the citation in People ex rel Nonhuman Rights Project, Inc $v$ Lavery 2014/ 'Lavery 2014') was: 'Black's Law Dictionary defines the term "person" as "[a] human being" or, as relevant here, "[a]n entity (such as a corporation) that is recognized by law as having the rights and duties [of] a human being" [emphasis added]: Garner (1999). The court also cited (Salmond 1947) for a similar view.
} 

conferring legal personality is inherently connected with the conferral of legal rights and the imposition of legal duties (see Gray 1909; Salmond 1916; Holland 1900; Pollock 1923).

The recognition of legal personality is a means of mutually respecting persons' rights and of enforcing legal control against any breaches thereof. When $\mathrm{P}$ is compelled by the society or the state (state and society are used interchangeably) to do or to forbear something in favour of $\mathrm{Q}$, and this compulsion is backed up by a threat of legal sanctions, it implies that the latter has a legal right and the former owes a corresponding duty (Corbin 1920). ${ }^{4}$ Hence, mutual rights and duties necessarily set up a legal relation between two persons, and no such relation can exist between a person and a thing or property such as an animal or a car (Corbin 1920). The relation between a person and a thing or property is rather 'physical'; ${ }^{5}$ however, the owner of the thing has many legal relations to other persons surrounding it, for example, preventing others from trespassing on it, or transferring it to anyone (Corbin 1920). To clarify, a legal relation represents facts embracing 'acts' and 'events' (Corbin 1920). As defined by Corbin, '[a]n act is one of that class of facts manifest to the senses that consists of voluntary physical movements ... of human beings' (Corbin 1920). An act also includes forbearance that denotes 'a consciously willed absence of physical movement. Animals other than men can act or forbear, but they do not become parties to a legal relation' (Corbin 1920). Corbin also defines 'events' to mean changes in the prevailing 'totality of facts, including the acts of human beings' (Corbin 1920). The assertion of the presence of a specific legal relation implicitly denotes the existence of certain facts expressing our existing mental concept of future

\footnotetext{
${ }^{4}$ For an analysis of the words 'rights' 'duties' and 'liabilities, see Corbin (1920).

${ }^{5}$ Physical Relation: 'A relation perceivable by the senses, between two physical objects. This would include relations of space, time, weight, color, density, and the like': Corbin (1920).
} 
145 social consequences (Corbin 1920). For example, Corbin provides that a 'statement 146 that a legal relation exists between $\mathrm{A}$ and $\mathrm{B}$ is a prediction as to what society, acting

147 through its courts or executive agents, will do or not do for one and against the other' 148 (Corbin 1920).

150 Unlike the relation between two individuals, the relation between an individual and a 151 corporation as a person may always be reduced to many legal relations separately, 152 with every individual standing behind it, though they are combined into one for 153 convenience (Corbin 1920). According to Salmond, a more satisfactory definition of 154 legal personality refers to the capacity for legal relations (Salmond 1916; Holland 155 1900). It means that a legal person shall have the capacity to establish, maintain and 156 effectuate legal relations with others, staying within the bounds of law.

158 The word 'rights' used in describing personality connotes legal relations between 159 persons. It is interconnected with duties and it contains legally enforceable claims 160 against others who are obliged not to breach such relations (Corbin 1920). A legal 161 person who knows that he/she has a certain right should be able to answer the 162 question: 'What must another do for me?' Corbin (1920). Hence the holder of rights 163 needs to have the awareness of its own entitlements and others' obligations of 164 performance. To compel such performance, the possessor of a right is entitled to 165 utilise the available legal recourses through the state (Corbin 1924). A right provides 166 an option to its holder to do or not to do a certain act that is not forbidden nor 167 commanded by law, while the act forms the content of the right in question (Terry 168 1916). Again, the existence of a right is a question of law, and the exercise of the right 169 entails its holder's conscious choice about doing or not doing something. 
171 As implied above, the enjoyment of one's rights requires the existence of duties of

172 others and their performance of those duties. Duties of a person as a constituent

173 element of legal relations are described as responsibilities commanded by law to do or

174 to forbear something for the benefit of others, the failure in, or disobedience of,

175 which will attract a remedy (Terry 1916; Corbin 1920). A person who bears a

176 particular duty with the knowledge of its existence, compulsion in its performance,

177 and sanctions against its disobedience, should be able to answer the question: 'What

178 must I do for another?' (Corbin 1920) Similar to the enjoyment of rights, the

179 performance of duties warrants their subject to have awareness of his/her/its

180 (subject's) relevant obligations, and to perform such obligations accordingly, in order

181 to avoid legal sanctions to be exerted by the society in the event of failure or

182 disobedience. For example, trespass to land or trespass to the person with the required

183 guilty mind demonstrates disobedience to one's obligations to refrain from doing so,

184 thus committing trespass attracts liability under both torts and criminal law.

186 The rights and duties discussed above as essential ingredients of personality justify

187 the ascription of personhood from the viewpoint of its purposes. The principal 188 purpose of legal personhood, conferred on whomever or whatever, is to facilitate the 189 regulation of human conduct by an organised society (Smith 1928). This facilitation is 190 effected through the regulation of the conduct of the subjects of law by reference to 191 legal relations, while conduct includes both acts and omissions (Terry 1916). 192 Generally, any legal liability is imposed for a breach of someone's right with an 193 ultimate objective of maintaining order in the society. For example, killing of a person 194 by an intentional act or a grossly negligent omission is penalised due to the violation 
195 of the right to life of the deceased. To this end, the imposition of a duty aims to 196 prevent consequences which may come about in the absence or non-performance of 197 the duty at hand; the duty not to kill someone aims to avoid that death, for example 198 (Terry 1916). This consequence can amount to a violation of one's right (Terry 1916). 199 According to Lundstedt's conception of the meaning of legal right, the sole purpose 200 for which law exists is to prevent harm of the community or to confer social benefit 201 (Lundstedt cited in Allen 1931). The law protects these rights by imposing duties on 202 others and providing remedies against any breach thereof. More precisely, as West 203 terms it, a 'breach of duty is an act of injustice' (West 2010).

205 The duty imposed on a person is said to correspond to the right of another where the 206 former owes the duty to the latter; however, when the duty is imposed by criminal 207 law, it is regarded as owed to the state (Terry 1916). Some of the paramount duties 208 imposed by law generally include: (i) duties not to do any act which will cause 209 injuries or death to others; (ii) duties of possessors of actively dangerous things, such 210 as ferocious animals or man-made treacherous products (industrial or social robots, 211 for example) to prevent them from causing harm; and (iii) duties not to take 212 possession of property in violation of others' rights or legal interest (Terry 1916). A 213 legal interest is defined as ' $[\mathrm{t}]$ he aggregate of the legal relations of a person with 214 respect to some specific physical object or the physical relations of specific objects' 215 (Corbin 1920). 
217 Case law has consistently recognised the correlative rights and duties that attach to

218 legal personhood. ${ }^{6}$ It is judicially recognised that ' $[\mathrm{s}] \mathrm{o}$ far as legal theory is

219 concerned, a person is any being whom the law regards as capable of rights and

220 duties. ... Persons are the substances of which rights and duties are the attributes. It is

221 only in this respect that persons possess juridical significance, and this is the exclusive

222 point of view from which personality receives legal recognition' (Lavery 2014,

223 citations omitted). Most recently the Supreme Court of New York (NY-SC) in Matter

224 of Nonhuman Rights Project, Inc. $v$ Stanley (Stanley) upheld that the autonomy and

225 self-determination of any entity are not regarded as the basis for granting it rights

226 (Stanley 2015). Rather, the Appellate Division of the NY-SC (NY-SCAD) in People

227 ex rel Nonhuman Rights Project Inc $v$ Lavery (Lavery), which was followed in

228 Stanley, applied the prevailing attributes of personality, in determining the

229 personhood of a chimpanzee, that legal personhood has unfailingly been defined by

230 reference to both rights and duties (Lavery 2014). Central to the legal personality is

231 thus the ability to enjoy rights and to discharge duties (Duff 1929).

233 Free will is a critical element of personhood where the person is subject of a legal

234 right, because its existence is needed to exercise such a right, and it is not necessary to

235 have this power for a person who is bound by a legal duty (Gray 1909). However, a

236 different view exists that gives emphasis to duties instead of rights with respect to a

237 juristic person (Machen Jr 1911). A 'juristic person', as Gray describes, is one who is

238 not a human being, but rather a legal person composed of humans with the objective

239 of advancing certain interests, for example states and corporations (Gray 1909). Also,

\footnotetext{
${ }^{6}$ The case can be found in: Smith v ConAgra Foods, Inc (2013) ; Calaway v Practice Mgt Servs, Inc (2010); Wartelle v Women's \& Children's Hosp, Inc (1997): Cited in People ex rel Nonhuman Rights Project Inc v Lavery (2014).
} 
with respect to affording legal personality, authorities primarily consider whether law

241 can address its commands to those who are seeking personhood, as understanding and

242 acting upon such commands is only possible for those who are rational beings having

243 the capability of feeling and volition (Machen Jr 1911). Gray thinks that there can be

244 no legal personhood without having a will to exercise the right, and its (right) owner

245 must exercise the willpower in enjoying it (Gray 1909). Linking this with the concept

246 of right, Salmond says that in order to have right, one must be capable of interests that

247 may be affected by others, and correspondingly, also be capable of duties not to act

248 affecting the interests of others (Salmond 1916).

250 Thus the idea of personhood entails an entity to be a legal subject able to enjoy rights

251 and to perform duties, rather than being merely an object, in order for it to be a legally

252 recognised person. This concept of personhood, developed by experts of Canon law in

253 the $13^{\text {th }}$ century (Pagallo 2013), continues to dominate the administration of justice to

254 date, as most recently interpreted by the NY-SC in Stanley, which involved the

255 determination of personhood of two chimpanzees (Stanley 2015). ${ }^{7}$

257 In a nutshell, the requirements or attributes of legal personhood are: (i) a person shall

258 be capable of being a subject of law; (ii) being a legal subject entails the ability to 259 exercise rights and to perform duties; and (iii) the enjoyment of rights needs to 260 exercise awareness and choice.

262 Different kinds of persons that may be recognised by various legal systems can be 263 classified as: normal human beings; abnormal human beings (eg, infants);

\footnotetext{
7 The case has been discussed at some length further later in this article.
} 
264 supernatural beings (eg, angels); animals; inanimate objects (eg, idols); and 265 incorporated entities (eg, corporations) (Gray 1909). This article examines the legal

266 status of the latter three categories, excluding human and supernatural beings, with a

267 view to assessing the presence of the personhood attributes in robots and in light of 268 these three. In doing so, an emphasis will be given to the corporate legal personality, 269 which is often compared with robots in advocating the latter's legal personality (see 270 Hallevy 2010a, b). ${ }^{8}$ Robots are also sometimes likened to animals (see Bertolini

271 2013). However, Bertolini rejects that analogy, asserting that the central argument of 272 those who make such a comparison - that weakly autonomous robots and animals 273 behave sensing the environmental conditions independently of human directions - is 274 not sufficient to equate these two unequals: one is natural whilst the other is a human 275 creation (Bertolini 2013). Therefore this untenable comparison does not warrant any 276 changes to be brought about in the existing legal paradigm by affording personality to 277 robots (Bertolini 2013). Both idols and chimpanzees have been included in the present 278 article in order to show the reasons for recognising the former's personality while 279 refusing the latter's. Those reasons will provide insight into the lack of substance in 280 the advocacy of robots' personhood.

\section{Corporations as a Legal Person}

283 A company or corporation (used interchangeably) from a legal viewpoint is an entity 284 created by humans and recognised by law as an artificial person having attributes of 285 personhood conferred on it through incorporation by a state agency, mainly for the 286 convenience of all others in dealing with this organisation, which operates for profits 287 or other purposes with perpetuity in its existence and simplicity in its relations with

\footnotetext{
${ }^{8}$ Idols are also regarded as a 'juristic person' as will be shown later in this article.
} 

changed to an association of individuals (Davis 1909); however, at present a single person is sufficient to form a company. ${ }^{9}$ Corporations are now major players in both national and international economies, while contemporary societies are intensely 292 dependent upon these entities: we are all affected by them one way or another. This 293 reality necessitates the regulation of corporations, which has ultimately become a part 294 of social governance (Farrar 2005). Despite such significance of corporations for 295 human societies, obtaining the recognition of corporations as a separate legal person 296 was a difficult task. The difficulty lies in the attribute that legal persons bear legal 297 duties in exchange for their legal rights (Lavery 2014). Given these personhood 298 attributes, it has 'puzzled legal theorists' (Ripken 2010) ${ }^{10}$ for years as to whether a 299 corporation should be regarded as a separate person independent of its owners and managers (see, for example, Freund 1897; Hallis 1930; Nekam 1938; Stoljar 1973;

301 Cohen 1935; Radin 1932; Vinogradoff 1924; Wolff 1938). Nevertheless the corporate 302 separate personality is now recognised in all legal systems, based mainly on the 303 principle established in Salomon v Salomon \& Co Ltd [1897] AC 22 though their 304 liabilities may vary depending on the specific provisions of a given jurisdiction. ${ }^{11}$ 305 This personality enables the entity to serve as a single contracting party independent 306 of its owners and managers, and this is said to be the first and foremost contribution 307 of corporate law (Kraakman et al. 2009). This personality has a strong bearing on its 308 operations and interaction with others.

\section{Significance of the Separate personality}

\footnotetext{
${ }^{9}$ For example, see s114 of the Corporations Act 2001 (Cth); s123 of the Companies Act 2006 (UK).

${ }^{10}$ This article has been generously followed in discussing the corporate personality section in the present article.

${ }^{11}$ In Germany, corporations cannot be held liable under criminal law, however can be fined for regulatory offences, in contrast, they can be criminally liable even for manslaughter in major common law countries including the United Kingdom, the United States, Australia.
} 
310 The separate personality bestows the legal capacity of entering into almost all legal

311 relations with other persons. ${ }^{12}$ It demarcates the assets of the entity itself and those of

312 its owners; as a result it can shield its own assets from the intervention of its owners

313 or their personal creditors, because company's creditors are given priority over

314 investors - this is called 'entity shielding' (see Hansmann et al. 2006).

315 Another important rule in this regard is 'liquidation protection', which makes 316 shareholders or their personal creditors unable to withdraw their investment at the

317 time of financial trouble of the company (Hansmann and Kraakman 2001). This

318 shielding makes corporate contractual commitments credible to the outside world

319 (Kraakman et al. 2009). A corporation is entitled to enter into a contract like an 320 individual (see s124 of the Corporations Act 2001 (Cth). Indeed, it can sue and be 321 sued; another important benefit of this personality is the elimination of the need to 322 name or specify in judicial proceedings, all shareholders and other individuals behind 323 the corporation that intends to sue another or is sued by others, such as a creditor or 324 regulator (Kraakman et al. 2009). All these entitlements are critical to the operation of 325 a business with a separate personality, as they enhance the credibility of corporate 326 transactions and afford simplicity in dealing with a corporation for business and 327 governance purposes (Kraakman et al. 2009). These benefits are convincing for the 328 separate personhood of corporations, and this has been granted based on the attributes 329 of rights and duties. Although there is almost complete unanimity on the need for 330 corporate personality, it is viewed differently in legal discourses that have contributed 331 to the emergence of different theories of corporations.

\footnotetext{
${ }^{12}$ See, for example, s 124 of the Corporations Act 2001 (Cth) in Australia. It beings with: 'A company has the legal capacity and powers of an individual...'
} 
333 There are three prominent theories of corporate separate personhood: (i) an artificial 334 and dependent person theory; (ii) an aggregate person theory; and (iii) a real and 335 independent person theory (Ripken 2010). These theories view corporations 336 differently from one another, to some extent. These theories are briefly discussed 337 below with a view to finding a rationale for corporate separate personhood (For a 338 detailed discussion of these theories, see Ripken 2010).

\section{Artificial and Dependent Person Theory}

340 The theory of artificial and dependent persons believes that there is no physical 341 existence of a corporation: it is an abstract idea constructed by law. So a corporation 342 is just a legal construct, an artificial creation of law and humans; its personhood is a 343 legal fiction conferred by law solely for the facilitation of trade and commerce 344 (Ripken 2010). Maitland stipulated that a corporation itself can do only one thing: 345 appoint an agent to act on its behalf (cited in Duff 1929). Duff explains that if 346 shareholders in a meeting adopt three resolutions - appointing an employee; entering 347 into a contract by accepting an offer; and inciting the commission of an offence - only 348 the first one would be the act of the entity: the other two may be either acts of its 349 agents or not acts at all, depending on governing laws (Duff 1929).

350 The second characteristic of a company under this theory is its dependence on law; as 351 Niman states, a corporation does not come into being until the legal formalities are 352 met and its incorporation is certified by the appropriate state agency (Niman 2012, 353 citations omitted).

354 Regarding the rights and duties which are our basic concerns, Gray asserts that the 355 name of a corporation is basically an abbreviation used in law and commerce in order 356 to confer specific rights on, and perform duties by, individuals contractually or 357 otherwise related to or affected by the entity (see Gray 1909; Wolff 1938). As stated 
359 about corporations, '[i]t is chiefly for the purpose of clothing bodies of men, in

360 succession, with these qualities and capacities, that corporations were invented, and

361 are in use.' However, English courts repeatedly rejected the notion that a corporation

362 is just a name to avoid the trouble with using the names of numerous individuals,

363 because it did not seem to reflect the economic and psychological facts of a 364 corporation with which the law must deal (for example, Salomon v Solomon Co Ltd 365 1897; Mlacaura v Northern Assurance Co 1925).

367 It is to be conceded that the personality of a corporation came into existence through 368 incorporation by appropriate state authorities as part of a legal process. However, the 369 concept of artificiality is old, and the assertion that the rights and duties of a 370 corporation represent those of individuals remained prevalent in this theory. This old 371 concept changed over time in the mid- $19^{\text {th }}$ century, which gave a perception that the 372 incorporation process is merely a formality. It is now widely believed that the 373 existence of a company is owed to the natural persons called 'corporators' who form 374 it, and this has significantly diminished the force of the artificial person theory 375 (Ripken 2010). An alternative view of the perception of a corporate entity as an 376 aggregate of persons emerged in the second half of the $19^{\text {th }}$ century (Ripken 2010).

\section{Aggregate Person Theory}

378 The main weakness in the aggregate person theory is that its proponents do not 379 recognise a corporation as a separate and distinct person. They believe that a 380 corporation is not an artificial entity nor merely a creation of law as such; rather it is 381 an organisation or association of a group of people who form its individual human 382 constituents and without whom it would not have any identity of its own or any ability 
384 Cressey stipulates, a corporation is virtually a manifestation of natural persons

385 because it is created, owned, managed and administered by those who thus become

386 the ultimate actors of the body corporate (cited in Ripken 2010). Diminishing the

387 distinct personality, the US-SC in Santa Clara County v Southern Pacific Railroad 388 Company (1886) 118 U S 394 in 1886 pronounced that company's properties are 389 those of the individuals behind it. Likewise, according to Morawetz (1886), this 390 theory reinforces that the rights and duties of a corporation are factually those of 391 corporators, rather than those of an imaginary person. Salmond spelt out that there are 392 some natural persons behind every corporation, and initially the interests of those 393 persons are fictitiously attributed to their corporation, and subsequently their conduct 394 or acts are also imputed to it in the same way (cited in Duff 1929). This means that a 395 company represents both the interests and the acts of individuals, rather than those of 396 its own in the true sense, hence a distinct personality does not exist according to this 397 theory.

399 This theory is thus in sharp contrast to the artificial person theory, as it recognises that 400 a corporation is not a fiction, but rather does exist as an aggregate of individuals, not 401 as a separate person independent of its corporators. The basic tenets of this theory are 402 the negation of artificiality in the corporation as a separate entity, and the merger of 403 individuals and the entity together, eliminating the distinction between a corporation 404 and its corporators in term of rights, duties, and properties. However, this does not 405 reflect the contemporary view of corporations. 
407 The limited liability feature of modern corporations stimulated the general public to invest in securities which contributed to dispersing the spectrum of shareholders and enlarging corporations by the early twentieth century. This development even more clearly separated the ownership and control of corporations, given the inability of the large number of widely scattered shareholders to stay interconnected and to control their entities, as observed by Berle Jr and Means (1932). This deep separation, which makes the aggregate theory largely redundant (Phillips 1994), has given birth to a new theory called the real and independent person theory.

\section{Real and Independent Person Theory}

The real and independent person theory argues that the corporate personality is both real and natural as opposed to fictitious, and that States have just recognised the existing fact, rather than creating it (Machen Jr 1911). Gierke posits that once an organisation has been created by a group of human beings, a body corporate or a corporate organism is founded per se, which is recognised by law in order to facilitate trade and commerce by and with this newly created entity (cited in Machen Jr 1911). They contend that the existence of corporations is an objective fact, and that the entities have a real presence in our society; therefore corporate life comes into existence independently of law, and States only officially recognise the pre-existing fact (Ripken 2010). This doctrine accepts the separation of the entity from its owners and others who are involved in the corporate enterprise, recognises the perpetuity of the organisation regardless of any changes in its ownership and management, and at the same time distinguishes between the personality of a natural person and that of a corporation (Ripken 2010). Machen asserts that when we admit a corporation is created by the State, it cannot be fictitious at the same time (Machen Jr 1911). 
433 Currently the predominant view is that corporations are real: we recognise that their

434 citizenship compares with that of humans, they pay taxes and bear social

435 responsibility, they can be held liable for committing both civil wrongs and crimes in

436 addition to regulatory breaches. We have thus brought them within the purview of

437 social governance as a necessity, in that we are all affected by them one way or 438 another.

440 Whichever theory we accept, in reality both individuals and corporations can be held

441 liable for corporate wrongdoings. ${ }^{13}$ This means that despite the separation of 442 personality by law, individuals behind a corporation are not immune from the liability 443 that may arise from the breach of a corporate duty committed by individuals wearing 444 the veil of incorporation. On the other hand, as well as managers/controllers, 445 shareholders may be held liable for corporate debts to varying extents, depending on 446 the type of their company. ${ }^{14}$ Any pecuniary fines paid by corporations are eventually 447 imposed on stockholders, who are the residual claimants of corporate assets. 448 Correspondingly, any profits of a corporation are likely to benefit its corporators in 449 the course of time, in the form of dividends, capital gains or residual payments. 450 Corporate personhood, discussed below, is based on these theories of corporations 451 and attributes of personality.

453 Corporation as a Legal Person - Do They Satisfy the Attributes of Personhood?

\footnotetext{
${ }^{13}$ See more than 50 sections listed in s1317E on civil penalty and Schedule 3 containing 346 sections on criminal liability of the Corporations Act 2001 (Cth), Australia.

${ }^{14}$ Generally, a company can be of different types by reference to the liability of its shareholders in the event of its winding up. These are: company limited by shares, company limited by guarantee, company limited by both shares and guarantees, unlimited company, and no liability company: For details (see Harris et al. 2016).
} 
454 Corporations are called a 'juristic person', the essence of which lies in subjection to duties, rather than in the possession of rights (Machen Jr 1911). Corporate personality will be negated if the ordinary meaning of personhood is applied, because it is not a rational being, it is incapable of understanding legal commands and it is unable to do anything without its human agents (Machen Jr 1911). So when law commands a corporation to do or not to do certain things, it goes in essence to the individuals behind it; if the commands are violated, a corporation can be penalised as a way of directly or indirectly punishing the people who manage (Machen Jr 1911) and/or own it. ${ }^{15}$ According to Machen $\mathrm{Jr}$ (2011), corporate entity is used by law as a mere sight aiming at shooting the individuals hiding behind it. So individuals are not immune from liabilities arising from failure in discharging corporate duties or in complying with law. ${ }^{16}$ Both corporations and individuals wearing the veil of incorporation can be held liable under administrative, ${ }^{17}$ civil (see, for civil cases, Hubbard 2014; Sexton et al. 2010), civil penalty ${ }^{18}$ and even criminal liability ${ }^{19}$ regimes. Notably, regarding offences, both the actus reus (physical element) and mens rea (mental element) of an

469 offence are imputed to the company from its directing mind and will under the 470 common law organic theory of corporation, also known as the directing mind theory 471 or the identification doctrine, as expounded by the House of Lords in Tesco

\footnotetext{
${ }^{15}$ The owners are punished in effect when a corporation is penalised in that any pecuniary penalties reduce the value of their ownership holdings, and if a corporate capital punishment is awarded, then the owners are in most cases likely to suffer even more financial losses given the additional costs involved in the winding up or liquidation procedure, which will be paid as a priority payment.

${ }^{16}$ For numerous civil cases where corporations and/or individuals were held liable for corporate wrongdoings (see Hubbard 2014; Sexton et al. 2010).

${ }^{17}$ See, for example of administrative actions against corporations and individuals, Australian Securities and Investment Commission (ASIC 2015).

${ }^{18}$ Recent leading cases in Australia under its corporate civil penalty regime: ASIC v Macdonald (No 11) (2009); ASIC v Macdonald (No 12) (2009); ASIC v Hellicar (2012); A v Healey (2011); ASIC v Healey (No 2) (2011).

${ }^{19}$ See for recent several manslaughter cases in the United Kingdom: Filedfisher (2015).
} 
472 Supermarkets Ltd v Nattrass [1972] AC $153 .{ }^{20}$ Put simply, only senior executives of a

473 company can be its directing mind and will.

475 Similar to the indirect imposition of duties and corresponding penalties on human

476 being who clothe the corporation, legal rights too, when conferred on such an entity,

477 are due to be carried to those individuals who compose it (Machen Jr 1911). Ihering

478 notes that individuals, not corporations, are the real subject of the rights conferred on

479 corporations (Machen Jr 1911). Moreover, the legal personhood of corporations is not

480 absolute because the corporate separate personality may be ignored for liability

481 purposes in some instances by lifting the corporate veil (see Sloan Shipyards

Corporation v Emergency Fleet Corporation 1921; United States v Walter 1923).

484 Hence, corporations are, in reality, formed by humans and recognised by the State as

485 being all for the purposes of human benefits. Individuals embody a corporation: the 486 rights and duties of the latter effectually refer to those of the former. When it comes to 487 any wrongdoings, both physical and mental elements are attributed from individuals 488 to their corporate entity. Hence, in recognising the juristic personality of a 489 corporation, all of the personality attributes of individuals behind it are directly 490 imputed to their corporation. We can now conclude that the personhood of 491 corporation does meet the needs of legal personality (i.e., subject of law, rights, 492 duties, awareness, and willpower).

\section{Idols as a Legal Person}

\footnotetext{
20 The doctrine was applied in a more recent case of Transco PLC v Her Majesty's Advocate (2004). For its initial consideration, see Lennard's Carrying Co Ltd v Asiatic Petroleum Co Ltd (1915). A discussion of this common law theory falls beyond the scope of this article, however, for its analysis at some length see Solaiman and Begum (2014).
} 
An idol is a statue created and worshipped by humans as a god or goddess, perhaps most popularly in the Hindu religion. As a legal person, a Hindu idol has been held to have peculiar desires and a will of its own which must be respected, as held by the Privy Council in Pramatha Nath Mullick v Pradyumna Kumar Mullick (1925) 27 BOMLR 1064 (Mullick) in 1925 (see also Yesey-Fitzgfrad 1925). Hence, Hindu idols have long been judicially recognised in some jurisdictions, such as India, as a legal person, founded upon religious customs (Duff 1929; Lord Shaw in Mullick 1925). Shaw J held in Mullick (1925), which involved a dispute arising out of the controlling and worship of a Hindu family idol, ruled that such an idol is a juristic person and held:

A Hindu idol is, according to long established authority, founded upon the religious customs of the Hindus, and the recognition thereof by Courts of law, a "juristic entity." It has a juridical status with the power of suing and being sued. Its interests are attended to by the person who has the deity in his charge and who is in law its manager with all the powers which would, in such circumstances, on analogy, be given to the manager of the estate of an infant heir, [i]t is unnecessary to quote the authorities; for this doctrine, thus simply stated, is firmly established.

The Privy Council further clarified that a Hindu idol is not a chattel or personal property as such. It ruled that 'this was not a dedication, in any sense of the word, of the idol as property, nor of the idol at all. It was a dedication of real estate in trust for the idol, recognised as a legal entity, to which such dedication might be made' (Mullick 1925). 
519 These powerful judicial stipulations resemble the most fundamental feature of 520 corporations in articulating the legal status of an idol.

522 Although an idol differs overtly from a company in terms of physique, they are 523 comparable to each other in that their attributes of personality are borrowed from 524 human beings who are lawfully entitled to manage them with all the powers, as with a 525 guardian or manager of an infant and his/her assets (Duff 1929; Lord Shaw in Mullick 526 1925). In other words, an idol's legal interests are attended to by its managers. 527 Savigny thus rightly compared a corporation with an idol in respect of juristic 528 personality, which is composed of humans (Duff 1929). Consistently, referring to the 529 capacity for rights and liabilities, Duff admits that a recognised idol is a legal person 530 as good as a human being and a body corporate (Duff 1929). This capacity does refer 531 to that of managers of respective idols. When an idol's legal personality comes to its 532 power of will, a question may emerge as to how to ascertain such a will. Perhaps the 533 best answer would be that whatever the relevant law regards as its power of will, 534 giving due consideration to the interests of the worshipers as well as social interests in 535 materialising the wishes of pious founders, will be the idol's will (Duff 1929; Lord 536 Shaw in Mullick 1925). To clarify further, the Privy Council in Mullick 1925 537 pronounced that the will of the idol will be expressed by its guardian, the manager.

539 Therefore, rights and duties of an idol are those of the individuals having managerial 540 powers. Based on the similarities between corporations and idols in terms of 541 personality attributes, we can draw a conclusion that an idol's personhood is justified, 542 and that the corpus of an idol is used just as a symbol of power, god or goddess, 543 whose affairs are managed by humans. 
546 An animal is distinct from corporations and idols in that it is naturally a living thing,

547 with its peculiar characteristics being vicious or otherwise, and is capable of doing 548 acts that include both things it has been trained for, and anything of its own will, 549 depending on the very nature of a particular animal and the erratic behaviour of others 550 that may cause the animal's behavioural deviation (Bertolini 2013). Bertolini (2013) 551 appreciates the prevailing owners' liability provisions for their animals' misconduct, 552 and in the same way he positively argues that the owner or user of the robot can be 553 held liable for the harm caused by robot. However, he also adds that makers or 554 manufacturers can also be held liable if their products were found to be defective 555 (Bertolini 2013).Although an animal's personality is not recognised in law, it has 556 recently and recurrently become an issue before the courts in the US, the decisions of 557 which would be useful for determining the eligibility of robots' personhood, 558 particularly with respect to robot's so-called 'autonomy', the central issue of 559 advocating the machine's personality.

560 On 30 July 2015, the NY-SC in a landmark judgment in Stanley (2015) pronounced 561 that chimpanzees are not legal persons. The verdict was delivered following a writ 562 petition of habeas corpus by an organisation, Nonhuman Rights Project, Inc (NhRP).

563 The NhRP submitted the writ petition for freeing two chimpanzees kept in a 564 laboratory of the Stony Brook University, New York for biomedical experimentation. 565 They first unsuccessfully lodged their petition on behalf of the detained chimpanzees 566 with the Suffolk County Supreme Court (Suffolk Court) in December 2013, where 567 their petition was dismissed by its Appellate Division on the ground that the NhRP 568 did not have the right to appeal on behalf of chimpanzees (NhRP 2015). In their 
569 petition, the NhRP asked for the termination of the chimpanzees' captivity and for 570 releasing them into the care of 'Save the Chimps', a sanctuary in Florida (NhRP

571 2015).They likened the animals' captivity to human imprisonment, and claimed that

572 the chimpanzees had the right to not be imprisoned against their will (NhRP 2015).

573 The NhRP took the dismissal as an error of the Suffolk Court and then moved to the 574 NY-SC in Manhattan in March 2015. They lodged their proceeding pursuant to Art 70 575 of the Civil Practice Law and Rules (CPLR) and under the common law for a writ of 576 habeas corpus on behalf of the two chimpanzees. Unlike the original petition in 577 Suffolk, this time they were initially successful in obtaining a show cause order from 578 the NY-SC issued by Judge Barbara Jaffe in the first of a two-step process (first show 579 cause and then determination). However, Jaffe $\mathbf{J}$ in the second step rejected the 580 petition in July 2015, pronouncing that chimpanzees are not legal persons, and the 581 court strictly relied upon the precedent set forth in the Lavery (2014) in 2014.

582 The petition required a determination as to whether chimpanzees are legal persons 583 entitled to bring a writ of habeas corpus, a legal challenge against unlawful detention 584 typically brought by human prisoners, and sometimes in child custody cases. The 585 NhRP tried to take advantage of the absence of definition of 'person' in both Article 58670 of the CPLR and the common law of habeas corpus (Stanley 2015). The Court 587 found no previous judicial decisions evidencing that such a writ had ever been granted 588 to anyone other than human beings under Article 70 or common law. Nonetheless, the 589 NY-SC had dealt with the petition referring to Lavery (2014), that the lack of 590 precedent does not in itself end the inquiry into whether habeas corpus relief may be 591 extended to chimpanzees (Stanley 2015). Notably, the petitioner had not claimed the 592 human rights of chimpanzees, but rather had contended that 'the law can and should 
593 employ the legal fiction that chimpanzees are legal persons solely for the purpose of 594 endowing them with the right of habeas corpus, as the law accepts in other contexts 595 the "legal fiction" that nonhuman entities, such as corporations, may be deemed legal 596 persons, with the rights incident thereto' (Stanley 2015). The petition likened 597 chimpanzees to humans and further maintained that 'because chimpanzees possess 598 fundamental attributes of personhood in that they are demonstrably autonomous, self599 aware, and self-determining, and otherwise are very much like humans, "justice 600 demands" that they be granted the fundamental rights of liberty and equality afforded 601 to humans' (Stanley 2015). ${ }^{21}$

602 Amicus curiae in presenting independent arguments made a reference to the definition 603 of 'person' provided in the New York State Penal Law (s10.7) that a person 604 conclusively denotes 'a human being, and where appropriate, a public or private 605 corporation, an unincorporated association, a partnership, a government or a 606 governmental instrumentality.' Amicus curiae opined that the personality of all these 607 entities is justified because they are composed of human beings (Stanley 2015). 608 Referring to this extension of the subjects of the penal provisions, Amicus curiae 609 persuasively argued that 'the expanded definition of person in a restricted context 610 connotes a legislative intent that the definition not be further expanded.... nowhere in 611 that statute are animals defined as persons' (Stanley 2015).

612 The Court critically examines the current trends towards the empathy for animals, 613 particularly the demands for pets' legal personhood. For example, given the rights, 614 love and attachment for pet animals, some commentators argue that animals are 615 currently 'quasi-persons' in law as they are entitled to some rights and protection 21 Autonomous intelligence denotes the 'capabilities for solving problems involving pattern
recognition, automated scheduling, and planning based on prior experience' (Koditschek 1989). 

though not others (Stanley 2015 citing Matambanadzo 2012). However, Jaffe J states that as the law presently regards, there is no 'in-between' position of personhood for the purposes of establishing rights because entities are categorised in a simple, binary, 'all-or-nothing' fashion (Stanley 2015, citations omitted).Distinguishing persons from things, Jaffe $\mathrm{J}$ adds that the beings recognised as persons have rights to enjoy and duties to perform, whereas 'things' do not have these legal entitlements and responsibilities (Stanley 2015, citations omitted). Her Honour thus reaffirms that legally, all animals, regardless of their level of intelligence and physical appearance, are property (Stanley 2015).

Jaffe J noted the previous 2014 determination of the NY-SCAD in Lavery (2014), which involved an identical issue, and the court ruled that ascribing legal personhood to chimpanzees is 'inappropriate as they are incapable of bearing any legal responsibilities and societal duties' (cited in Stanley 2015). The NY-SCAD, citing several judicial decisions, distinguished between chimpanzees and currently recognised legal persons, and stated that corporations are composed of human beings, therefore they are able to bear legal duties in return for their legal rights, hence their legal personality is justified (Lavery 2014, citations omitted). Alongside the reliance on judicial authorities, the courts in both Lavery (2014) and Stanley (2015) also noted, as further sources of support, the definition of person provided in Black's Law Dictionary stated earlier. The Court in Lavery (2014) finally affirmed the denial of writ of habeas corpus and held that:

A chimpanzee was not a 'person' entitled to the rights and protections afforded by the writ of habeas corpus ... because animals, unlike human persons, corporations, and municipal entities, could not bear any legal duties, submit to societal responsibilities, or be held legally accountable for their actions; the incapability to bear any legal 

chimpanzees legal rights.

643 Jaffe J, in deciding the personhood of chimpanzees in Stanley (2015), overtly relied 644 upon the precedent set out in Lavery (2014), and rejected the petitioner's argument 645 against the applicability of the previous decision 'that the decision in Lavery (2014) is

646 based on an erroneous legal analysis or "unsettled" law is immaterial' (Stanley 2015).

647 Her Honour thus finally dismissed the proceeding in Stanley (2015) stating that 648 Lavery (2014) has binding effects according to the doctrine of precedent. Therefore, 649 chimpanzees are not legal persons based precisely on the lack of being capable of 650 rights and duties, an essential requirement of personhood (Stanley 2015; Lavery 651 2014)), despite the important pieces of scientific expert evidence presented before the 652 Court in Stanley (2015) that: ‘ ... humans and chimpanzees share almost 99 percent of their DNA, and chimpanzees ... closely related to human beings .... They share with humans similarities in brain structure and cognitive development, including a parallel development of communications skills, as shown by their use and understanding of sign language.... Chimpanzees also demonstrate self-awareness, recognizing themselves in mirrors and photographs and on television, and have the capacity to reflect on their behavior. They manifest a capacity for empathy, are attuned to the experiences and emotions of others, and imitate and emulate others.... They behave in ways that reflect moral inclinations ... and demonstrate compassion and depression when a member of their community or familial group dies .... They also have a cooperative social life ... engage in imaginary play, and display a sense of humor ....

664 Therefore both Stanley and Lavery categorically rejected the demand for personhood 665 of chimpanzees, which are argued to be closest to humans in terms of appearance and 
666 of some basic human attributes. Both courts reinforced that a legal person must have

667 the capability of rights and duties, which requires the ability to properly understand

668 and follow the commands of law, and that no derogation from this critical need is

669 currently permissible in legal domains unless any statutes specifically provide

670 otherwise. The NY-SC further confirmed, no any attributes of human beings (as

671 identified in the above quotation of scientific evidence on chimpanzee) other than

672 being capable of rights and duties, nor the look-like physical appearance of any

673 'things', is a determinant in deciding the legal personality of any entities. We can now

674 look to the position of robots.

\section{Industrial Robots as a Potential Legal Person}

676 A robot as a possessor of artificial intelligence (PAI) is said to have five attributes: (i)

677 the ability to communicate with others; (ii) internal knowledge, ${ }^{22}$ (iii) external or 678 outside world knowledge; ${ }^{23}$ (iv) some degree of intentionality; ${ }^{24}$ and (v) some degree

679 of creativity. ${ }^{25}$ Despite having all these, robots are presently recognised as a product 680 or property at law (see Bertolini 2013; Sexton et al 2010; Hubbard 2014). Floridi 681 (2009) compares robots with tools which are no different from hammers. However, in 682 view of the above attributes, some commentators are arguing for partial (quasi) or 683 full-fledged personhood of these machines.

684 Asaro (2007) proposes a concept of creating 'quasi-persons' for robots, which will 685 enjoy only partial rights and duties. Solum (1992) argues for a 'borderline status' 686 though indecisively. He critically analysed the personhood of a PAI relying on two 687 different tests: (i) whether a PAI can serve as a trustee; and (ii) whether a PAI can be

\footnotetext{
${ }^{22}$ Some knowledge about themselves - what they need, what they think etc.

${ }^{23}$ Awareness of the outside world, past experience etc.

${ }^{24}$ The ability to act towards achieving specific goals.

${ }^{25}$ For details of these attributes, see Schank (1987).
} 

granted the rights of constitutional personhood. He has provided two scenarios for these two tests and has discussed potential objections that may be raised against a PAI's personality claim (Solum 1992). Regarding the first test, he identified two objections: the reasonability objection and the judgment objection. Three different potential objections have been discussed in relation to the second test: a PAI is not a human; the missing-something argument; and a PAI ought to be property. ${ }^{26}$ Having addressed all these potential issues, Solum could not firmly conclude that a PAI be granted legal personality. Rather he has argued for a borderline status in some way, pointing out reasons for hesitation and uneasiness surrounding the personhood, even against this new approach (Solum 1992). However, he has clearly mentioned that 'thinking about personhood for a PAI forces us to acknowledge that we currently lack the resources to develop a fully satisfactory theory of legal and moral personhood' (Solum 1992). Quite logically, Solum (1992) finally concludes in favour of the 'rights and duties' construct of legal personality.

It should be noted that while arguing for a borderline status, Solum refers to the behavioural aspect of these machines and submits that they 'behaved the right way and if cognitive science confirmed that the underlying processes producing these behaviors were relatively similar to the processes of the human mind, we would have very good reason to treat an AI as persons' (Solum 1992). As noted earlier, this point had been strongly raised and considered carefully by the NY-SC in Stanley in 2015, following credible evidence in favour of chimpanzees' personality, and it did not succeed (Stanley 2015, citations omitted). It means we are not finding any compelling reasons for robots' legal personality in this argument.

\footnotetext{
${ }^{26}$ Discussions of these arguments and objections at some length have been avoided in order to keep this piece in a manageable size. For details, see Solum (1992).
} 
711 Hallevy (2010a,b) seems to be a frontrunner in soliciting the world for robots' full

712 personality, based mainly on an analogy between robots and corporations with respect

713 to criminal liability, though he has sometimes compared robots with animals as well

714 (see Hallevy 2010a, b). The gist of his (Hallevy 2010a, b) arguments is, in his own

715 words:

716

717

718
Why should AI entities be different from corporations? AI entities are taking larger and larger parts in human activities, as do corporations. Offenses have already been committed by AI entities or through them. AI entities have no soul, and some AI entities have neither body nor soul. Thus, there is no substantive legal difference between the idea of criminal responsibility imposed on corporations and on AI entities. It would be outrageous not to subordinate them to human laws, as corporations have been. ... What else is needed?

While we disagree with the concept that robots have committed offences in the true sense, the above quoted assertions implicitly deny or plainly overlook the fact that any punishment imposed on a corporation effectively punishes human beings behind it (managers and/or owners). Likewise, this article advocates punishing individuals whose fault, if any, caused the robot's malfunction contributing to harm sustained by humans. To the best of our understanding, Hallevy's submissions in two of his articles (Hallevy 2010a, b) and in his book titled When Robots Kill: Artificial Intelligence under Criminal Law - strongly criticised by Charney (2015), - contain fundamentally the same arguments in favour of robots' criminal liability which entails separate legal personality. He has endeavoured to demonstrate that robots have the ability to commit actus reus of different types of offences with the requisite negligence and subjective mens mea, and therefore the machines themselves should be punished, and Hallevy argues that the objectives of punishment can be achieved by 
737 punishing these machines (Hallevy 2010a, b; Hallevy 2013). An analysis of the

738 constituent elements of different types of offences, along with the objectives of

739 punishment, a huge task by itself, obviously falls outside the scope of the present

740 article, which aims to be confined to the attributes of legal personality alone.

741 However, interestingly, he has recommended imposition of criminal liability on

742 robots without having to justify their legal personality anywhere in his articles apart

743 from superficial comparison with corporations (Hallevy 2010a, b; Hallevy 2013).

744 While a separate initiative is intended to be undertaken to critically analyse Hallevy's

745 claims about robots' physical and mental capabilities and the justifications for

746 applying human punishment to machines, from our present perspective there is

747 evidence that industrial and social robots are still a long way off from attaining such

748 human capabilities (see Weng et al. 2009; Demaitre 2016). Sartor (2009) asserts that

749 'the substitution of intelligent machine for humans in creative tasks is very far away'.

750 Further to those claims arguing robots' lacking of the requisite capability, Solum

751 (1992) iterates that robots do lack several critical attributes of personhood, such as,

752 intentionality, desires and interests, and therefore they lack the prerequisites laid

753 down for attributing criminal liability. ${ }^{27}$ All these are relevant to the commission of

754 actus reus with mens rea. For example, an act constituting actus reus requires 'a

755 volitional bodily movement' exercising power of will (Terry 1916), which cannot

756 exist in an entity that lacks, intentionality, desires and interests. Vladeck (2014)

757 mentions that the current law is not necessarily equipped to deal with the incidents in

758 which injuries will be caused by malfunction of such machines in the absence of a

759 principal directing the unlawful acts.

27 Although the notion of BDI (Belief-Desire-Intention) plays an important role in Multi Agent Systems (Rao and Geogeff 1995), these terms have a very technical meaning in that context, which does not entirely correspond to that intended by Solum. 
761 Therefore, robots are still being justifiably treated as 'products' for the purposes of

762 liability (Bertolini 2013). Some commentators suggest that even if we compare robots

763 with corporations, with respect to rights and responsibilities, a separate set of laws

764 would be needed for robots (Weng et al. 2009). In contrast to Hallevy, they (Weng et

765 al. 2009) validly point out that even if robots are ever held responsible for their

766 actions, a major issue will be determining punishment. They raise doubts about the

767 effectiveness of applying human punishment to robots, and refer to Asaro who utterly

768 denied the usefulness punishment claimed by Hallevy (Weng et al. 2009). Charney

769 (2015) has unequivocally denied Hallevy's arguments regarding robots' physical and

770 mental capabilities with reasons, and so also the justifications for applying the

771 conventional criminal punishments developed for and applied to humans.

773 In anticipation of creating fully autonomous machines in the future, Vladeck (2014)

774 advocates robots' personhood for civil law purposes at some point, by arguing that the

775 ascription of personality would resolve the agency issue because the machines

776 themselves will become principals in their own right and then self-insurance will be

777 required in order to meet any legal obligations arising from the damage caused by

778 their conduct. He then suggests that a broader range of 'audience', including the

779 owner of the faulty machine, will participate in funding the insurance (Vladeck

780 (2014). These arguments seem self-conflicting in that when the machine will be a

781 separate person, why should 'other persons' pay for the insurance of robots? Then a

782 counter question may be raised as to who pays for the corporate insurance. The

783 answer would be the corporation itself, which is made up of human beings through

784 whom the entity operates as it does not have any physical or intellectual ability to do

785 anything whatsoever without its human agents. This is a critical point where machines 
made by humans differ absolutely from corporations. Quite consistently, Bertolini

787 (2013) argues in respect of civil liability that even if a separate personality is

788 attributed to a software agent, it does not make any difference with respect to liability

789 because the same humans or corporations standing behind it will still have to bear the

790 liability unless robots earn revenue from their operation.

792 Having shown the aforesaid rebuttals of Hallevy's solicitation for robots' personhood,

793 we consider that no further discussion of elements of crime is warranted in this article

794 to determine robots' personhood attributes. Instead, if we turn to our requirement of 795 the capability of rights and duties, robots are unlikely to meet the judicial 796 interpretations of this essential requisite, given that they are human-made products 797 with limited self-control as programmed-to date, particularly those used in industrial 798 and social sectors. Other human characteristics as found in chimpanzees, even if they 799 are present in robots, will not help much in conferring legal personhood on these 800 machines as those were rejected by the NY-SC in Stanley. The arguments for 801 corporate personality may apply to idols' personhood, as their interests are attended to 802 by humans and any religious devotion can be expressed only by human beings in an 803 acceptable manner, but the same rationales do not apply to robots and chimpanzees. 804 Rather, the latter two, robots and chimpanzees, may be compared to each other to 805 some extent, in terms for example of temperament, ability to act, but those are 806 insufficient for separate personhood as decreed judicially. It could also be argued that 807 an idol can be constructed with a physically unique appearance as an art, and can 808 therefore be bodily destroyed as well. These features of an idol may equally apply to 809 robots. However, they are, as artefacts, just objects, therefore are not directly subjects 810 of legal rights and duties. Referring to robots as artefacts, Leenes and Lucivero (2014) 
811 emphasise 'they do not have legal rights and legal duties and they cannot perform

812 legal acts'. Nevertheless, as alluded to earlier, a Hindu idol is recognised as a legal

813 person clearly because of its being a juristic person that distinguishes it from a robot.

815 As Jaffe J points out in Stanley (2015, citations omitted), referring to rights and duties

816 for the purposes of legal personhood, creatures are categorised into two: either a legal

817 person or not ('all-or-nothing' fashion). If we give due consideration to the foregoing

818 discussion of legal personality in respect of corporations, idols and chimpanzees, we

819 can logically infer that robots, as a prima facie case, should not be granted

820 personhood, precisely because they do not meet the fundamental tenets of such legal

821 recognition as is inextricably linked with rights and duties. Through this link,

822 personhood is generally attached to human beings, and although law recognises

823 personality of corporations in all legal systems, and of idols in some jurisdictions,

824 these latter two are juristic persons composed of human beings one way or another,

825 and they cannot do anything without their human agents. Therefore, the rights and

826 duties relevant to their personality refer basically to those of humans behind them,

827 which stands in stark contrast to the advocacy for robots' personhood. When we argue

828 for robots' personality on the basis of artificial knowledge, or ability to make

829 independent decisions of their own, they still cannot satisfy the personhood attributes

830 as interpreted by both the judiciary and academia. Chimpanzees had all of these

831 attributes which are argued to be present in robots; nonetheless the repeated appeals

832 for the animals' personality have failed mainly due to their inability to perform duties.

833 Hence any move to obtain robots' personality is arguably destined to be unsuccessful

834 at this stage. Therefore we can conclude that robots are yet to be competent to have

835 independent personality. 
837 The determination of personality in order to identify the subject of law is the foremost 838 requirement of a legal solution to any dispute, because a law can be broken by its 839 'subjects' alone. Levy, like many others, predicts that robots will be found in the 840 majority of households by the end of the $21^{\text {st }}$ century (Weng et al. 2009). Meanwhile, 841 robots are being used in their millions, and have already proved sometimes dangerous, 842 causing significant amounts of harm. The personality of robots has thus been a critical 843 concern for many countries around the world.

844 The proponents of robots' personality rely basically on the personhood of 845 corporations, ignoring the fundamental consideration that corporate personality is 846 essentially a symbol of people standing behind the entity. The rights and duties of a 847 corporation resemble those of individuals who own and manage it, as alluded to 848 earlier; this is where the justification for corporate personhood lies. On the other hand, 849 the rationale for the recognition of idols' personality is akin to that of corporations in 850 that idols' rights and duties are attended to by their managers or custodians, who are 851 human beings. Thus robots are not comparable with either of these two recognised

852 legal persons. Rather, these machines can be better compared to animals in terms, for 853 instance, of so-called autonomy, self-awareness, or self-determination, though the 854 latter may be more autonomous compared to the former; and they are different by 855 nature - one is a human-made product, whilst the other is a living animal. However, 856 they are again similar, as both of them are regarded as property and thus are mere 857 'objects' of law, rather than 'subjects'. Leenes and Lucivero (2014) reinforce that 858 from legal perspective, robots are 'treated as tools and it is always a human being that 
859 is legally responsible for the robot's actions and hence responsible for ensuring that 860 they operate within the boundaries of the law.'

862 Autonomy and self-determination are not regarded as foundations of conferring legal 863 rights on any entity (Stanley 2015). The NY-SCAD in Lavery reaffirmed that rights 864 cannot be recognised in isolation from societal considerations, and thus granting legal 865 rights has historically been attached to the imposition of social obligations and duties 866 (Lavery 2014). As a member of a society, everyone should be subject to rights and 867 duties in order to live in an orderly manner. This subjection requires a being to have 868 the capability of these two attributes. Principles of social contract thus warrant 869 reciprocity between rights and duties (Lavery 2014, citations omitted). Pursuant to 870 this view, rights of persons are recognised in exchange for an express or implicit 871 agreement from them to submit to social duties (Lavery 2014). A right is attached to 872 moral agency and to the ability to shoulder social responsibility in exchange for that 873 entitlement (Lavery 2014, citations omitted). According to Bryson (2010), 'calling a 874 robot a moral agent is not only false but an abrogation of our own responsibility'.

876 The capability of rights and duties is therefore the sole attribute that is exclusively 877 considered by courts in determining legal personality of any entities, in the absence of 878 any succinct statutory provisions defining personality of any beings. Both 879 chimpanzees and robots lack this critical attribute as demonstrated previously.

880 Industrial and social robots have been empowered to do different types of acts for us. 881 In doing their jobs, robots have already malfunctioned resulting in enormous harm. 882 The machines might have gone beyond their programmed functions for some reason, 
such as internal defects in manufacturing, or operational mistakes at some stage, or a

884 plausible reason that could never be detected. In the event of not finding any fault or

885 scientific reason for robots' malfunction, the resultant harm should be redressed under

886 a mandatory insurance system. Otherwise, we recommend that legal persons from

887 either or both of the supply and user sides of the faulty robots be held liable for the

888 harm in question, depending on the cause of their wrongful conduct and the 889 corresponding involvement or fault of the legal persons (corporations and humans) in

890 a given case. Nugenborg, comparing robots with pets, advocates owner's liability 891 (Weng et al. 2009; see also Leenes and Lucivero 2014), while others prefer 892 manufacturers' liability under the product liability regime (see Bertolini 2013). 893 Liability is, for a rational being, an incentive, rather than a deterrent, in the sense that 894 it inspires fear in wrongdoers, contributing to compliance with law and to the resultant 895 prevention of harm (Allen 1931). Granting legal personality to robots may not be a 896 panacea; rather it may turn out to be Pandora's box, if we transform the machines to 897 our masters: as Smith (1928) commented, '[1]egal personality is a good servant, but it 898 may be a bad master'. The robots' personality could be that 'bad master', as recently 899 Stephen Hawking, like many others, has given an alarming warning that artificial 900 intelligence could end humankind (Cellan-Jones 2014). The personality in question 901 may thus exacerbate the dangers by exonerating humans from liability and thereby 902 diluting the effectiveness of deterrence. Moreover, robots do not as yet meet the 903 requirements of personality, and we also need to think about the query and concerns 904 expressed by Sartor (2009) in relation to robots: 'Shall we delegate so much to them, 905 and become so dependent on them that we will lose our ability to think and act on our 906 own?' In response, we may concur with Bryson's view that 'we are obliged not to the 

robots, but to our society. We are obliged to educate consumers and producers alike to their real obligations with respect to robotics' (Bryson 2010).

\section{References}

Alemzadeh1 H, Iyer1 RK, Kalbarczyk1 Z, Leveson N, Raman J (2015) Adverse events in robotic surgery: a retrospective study of 14 years of FDA data. http://arxiv.org/ftp/arxiv/papers/1507/1507.03518.pdf. Accessed 25 December 2015

Allen CK (1931) Legal Duties. Yale Law Journal 40(3):331-380.

Asaro Peter (2007) Robots and responsibility from a legal perspective.

http://www.peterasaro.org/writing/ASARO\%20Legal\%20Perspective.pdf. Accessed 20 December 2015

ASIC (2015), ASIC enforcement outcomes: January to June 2015. http://asic.gov.au/regulatory-resources/find-a-document/reports/rep-444-asicenforcement-outcomes-january-to-june-2015/. Accessed 24 December 2015

Berle AA Jr. and Gardiner C Means (1932) The modern corporation and private property. The Macmillan Company, New York

Bertolini Andrea (2013) Robots as products: the case for a realistic analysis of robotic applications and liability rules. Law, Innovation and Technology 5(2): 214-247.

Blumberg PI (1993) The multinational challenge to corporation law: the search for a new corporate personality. Oxford, Oxford University Press

Bora K (2 July 2015) Volkswagen German plant accident: robot grabs, crushes man to death. The International Business Times. http://www.ibtimes.com/volkswagengerman-plant-accident-robot-grabs-crushes-man-death-1993475. Accessed 7 December 2015

Blyth EK (1906) Moral personality and legal personality. Canadian Law Review $5(3): 166-172$

Bryson JJ (2010), Robots should be slaves. In: in Wilks Y (ed), Close engagements with artificial companions: key social, psychological, ethical and design issue. John Benjamins Publishing Company, Amsterdam pp 63-74

Cellan-Jones R (2014) Technology: Stephen Hawking warns artificial intelligence could end mankind' http://www.bbc.com/news/technology-30290540. Accessed 10 January 2016 
950 Charney R (2015) Can android plead automatism? A review of when kill: artificial 951 intelligence under the criminal law by Gabriel Hallevy. University of Toronto 952 Faculty of Law Review 73(1): 69-72

953

954 955

956

957 958 959 960

961

962

963

964

965

966

967

968

969

970

971

972

973

974

975

976

977

978

979

980

981

982

983

984

985

986

987

988

989

990

991

992

993

994

995

996

997

998

Cohen FS (1935) Transcendental nonsense and the functional approach. Columbia Law Review 35 (6): 809-849

Cressey DR (1989), The poverty of theory in corporate crime research. In: Laufer WS, Adler F (eds) Advances in Criminological Theory - Volume One. Transaction Publishers, New Brunswick pp 31-55

Cookson C (11 December 2015) Scientists appeal for ethical use of robots. The Financial Times, UK

Corbin AL (1920) Legal analysis and terminology. Yale Law Journal 29 (2):163-17

Corbin AL (1924) Rights and duties. Yale Law Journal 33(5):501-527

Davis JP (1909) Corporations: a study of the origin and development of great business combinations and of their relation to the authority of the state. New York: B Franklin

Demaitre E (2016) Five robotics predictions for 2016. Robotics Business Review http://www.roboticsbusinessreview.com/article/five_robotics_predictions_for_2016/m edical_assistive. Accessed 19 January 2016

Dhillon BS (1991) Robot reliability and safety. http://link.springer.com/chapter/10.1007/978-1-4612-3148-6_4\#page-2. Accessed 14 December 2015

Duff PW (1929) The personality of an idol. Cambridge Law Journal 3(1):42-48

Farrar J (2005) Corporate governance - theories, principles and practice. Melbourne, Oxford University Press

Filedfisher (2015), 'Corporate manslaughter case tracker. http://www.fieldfisher.com/media/3694153/corporate-manslaughter-tracker.pdf. Accessed 15 December 2015

Floridi L (2009) Artificial companions and their philosophical challenges. Dialogue and Universalism 19:31-36

Freund E (1897) The legal nature of corporations. Chicago, The University of Chicago Press

Garner BA (ed in chief) (1999) Black's law dictionary. St Paul, Minn, West Group

Gray JC (1909) The nature and sources of the law. York, Columbia University Press

Hallevy G (2010a) Virtual criminal responsibility. Original Law Review 6(1):6-27 
Hallevy G (2010b) The criminal liability of artificial intelligence entities - from

Hallevy G (2013) When robots kill: artificial intelligence under criminal law. Boston, Northeastern University Press

Hallis F (1930) Corporate personality: a study in jurisprudence. London, Oxford University Press

Hansmann H, Kraakman R, Squire Richard (2006) Law and the rise of the firm. Harvard Law Review 119(5):1335-1403

Hansmann H, Kraakman R (2001) The essential role of organisational law. Yale Law Journal pp 110(3):387-440

Harris J, Hargovan A, Adams M (2016), Australian corporate law. Chatswood, NSW, LexisNexis Butterworths

Health and Safety Executive (HSE) UK (2012) Collision and injury criteria when working with collaborative robots. http://www.hse.gov.uk/research/rrhtm/rr906.htm. Accessed 17 December 2015.

Holland TE (1900) The elements of jurisprudence. New York, Oxford University Press

Hubbard F P (2014) "Sophisticated Robots": balancing liability, regulation, and innovation. Florida Law Review 66(5):1803-1872

International Federation of Robotics (IFR) (2015) Industrial robot statistics. http://www.ifr.org/industrial-robots/statistics/. Accessed 22 October 2015

Koditschek DE (1989) Robot planning and control via potential functions. In: O Khatib O, Craig J J, Lozano-Pérez T (eds) The robotics review 1. Cambridge MA, The MIT Press pp 349-367

Kraakman R et al. (2009) The anatomy of corporate law - a comparative and functional approach. Oxford, Oxford University Press

Leenes R, Lucivero F (2014) Laws on robots, laws by robots, laws in robots: regulating robot behaviour by design. Law, Innovation and Technology 6(2):193-220

Machen AW Jr (1911) Corporate personality. Harvard Law Review 24(4):253-267

Matambanadzo SM (2012) Embodying vulnerability: a feminist theory of the person. Duke Journal of Gender Law \& Policy 20:45-83

Morawetz V (1886) A treatise on the law of private corporations. Boston, Little, Brown \& Co 
1049

1050

1051

1052

1053

1054

1055

1056

1057

1058

1059

1060

1061

1062

1063

1064

1065

1066

1067

1068

1069

1070

1071

1072

1073

1074

1075

1076

1077

1078

1079

1080

1081

1082

1083

1084

1085

1086

1087

1088

1089

1090

1091 Sartor G (2009) Cognitive automata and the law: electronic contracting and the 1092

Nekam A (1938) The personality conception of the legal entity. Cambridge, Harvard University Press

Niman J (2012) In support of creating a legal definition of personhood. Journal of Law and Social Deviance 3:142-244

Noack R (2 July 2015) A robot killed a factory worker in Germany- So who should go on trial?' The Washington Post, USA

Nonhuman Rights Project (2015), Judge recognizes two chimpanzees as legal persons, grants them writ of habeas corpus' Press Release, New York. http://www.nonhumanrightsproject.org/2015/04/20/judge-recognizes-two-

chimpanzees-as-legal-persons-grants-them-writ-of-habeas-corpus/. Accessed 17 December 2015

Nygh PE (ed) (1997) Butterworths Australian legal dictionary. Adelaide, Butterworth

Pagallo U (2013) The laws of robots - crimes, contracts, and torts. Dordrecht, Springer

Phillips M J (1994) Reappraising the real entity theory of the corporation. Florida State University Law Review 21(4):1061-1123

Pollock S F (1923), A first book of jurisprudence. London, Macmillan \& Co

Radin M (1932) The endless problem of corporate personality. Columbia Law Review 32(4):643-667

Rao AS, Georgeff MP (1995) BDI agents: from theory to practice. 312-319

https://www.aaai.org/Papers/ICMAS/1995/ICMAS95-042.pdf. Accessed 5 November 2016

Ripken SK (2010) Corporations are people too: a multi-dimensional approach to the corporate personhood puzzle. Fordham Journal of Corporate \& Financial Law 15:97177

Rory CJ (2014) Technology: Stephen Hawking warns artificial intelligence could end mankind. http://www.bbc.com/news/technology-30290540. Accessed 10 January 2016

Salmond JW (1916) Jurisprudence. London, Stevens and Haynes

Salmond JW (1947) Jurisprudence. London, Sweet and Maxwell

intentionality of software agents. Artificial Intelligence and the Law 17(4): 253-290

Schank RC, 'What is AI, anyway?' (1987) AI Magazine 8(4):59-65. 
1095

1096

1097

1098

1099

1100

1101

1102

1103

1104

1105

1106

1107

1108

1109

1110

1111

1112

1113

1114

1115

1116

1117

1118

1119

1120

1121

1122

1123

1124

1125

1126

1127

1128

1129

1130

1131

1132

1133

1134

1135

1136

1137

1138

1139

1140

1141

1142

1143
Sexton PA, Suroff AT, Zmijewski DR, McDowell LN ((2010) Recent development in products, general liability, and consumer law. Tort Trial \& Insurance Practice Law Journal 45(2):517-542

Smith B (1928) Legal personality. Yale Law Journal 37(3):283-299

Solaiman SM, Begum A (2014) Impunity of frequent corporate homicides by recurrent fires at garment factories in Bangladesh: Bangladeshi culpable homicide compared with its equivalents in the United Kingdom and Australia. The Company Lawyer 35(10):289-309.

Solum LB (1992) Legal personhood for artificial intelligence. North Carolina Law Review 70(4):1231-1287

Stoljar SJ (1973) Groups and entities: an inquiry into corporate theory. Canberra, Australian National University Press

Terry HT (1916) The correspondence of duties and rights. Yale Law Journal 25(3):171-193

Vinogradoff P (1924) Juridical persons. Columbia Law Review 24(6):594-604

Vladeck DC (2014) Machines without principals: liability rules and artificial intelligence. Washington Law Review 89(1):117-150

Weng YH, Chen CH, Sun CT (2009) Toward the human-robot co-existence society: on safety intelligence for next generation robots. International Journal of Social Robotics 1:267-282

West R (2010) Rights, harms, and duties: a response to justice for hedgehogs. Boston University Law Review 90:819-837

Wolff M (1938) On the nature of legal persons. Law Quarterly Review 54(4):494521

Yesey-Fitzgfrad SG (1925) Idolon fori. Law Quarterly Review 41(4):419-422.

\section{Cases}

Amadio v Levin [Pa 1985] 501 A2d 1085

A v Healey [2011] FCA 717

ASIC v Healey (No 2) [2011] FCA 1003

ASIC v Hellicar [2012] HCA 17

ASIC v Macdonald (No 11) [2009] NSWSC 287 
1144

1145

1146

1147

1148

1149

1150

1151

1152

1153

1154

1155

1156

1157

1158

1159

1160

1161

1162

1163

1164

1165

1166

1167

1168

1169

1170

1171

1172

1173

1174

1175

1176

1177
ASIC v Macdonald (No 12) [2009] NSWSC 714

Bumper Development Corp Ltd v Commissioner of Police of the Metropolis and Others (Union of India \& Others) [1991] 4 All ER 638

Byrn v New York City Health \& Hosp Corp [1972] 286 N E 2d 887

Calaway v Practice Mgt Servs, Inc [2010] Ark 432

Lennard's Carrying Co Ltd v Asiatic Petroleum Co Ltd [1915] ACT 705

Matter of Nonhuman Rights Project, Inc v Stanley [2015] NY Slip Op 31419(U)

'Stanley (2015)

Mlacaura v Northern Assurance Co [1925] AC 619

Nydam v R [1977] VR 430

People ex rel Nonhuman Rights Project, Inc v Lavery [2014] 124 A D 3d 148

Salomon v Solomon Co Ltd [1897] AC 22

Sloan Shipyards Corporation v Emergency Fleet Corporation, (1921) 258 U S 549

Smith v ConAgra Foods, Inc [2013] Ark 502

Transco PLC v Her Majesty's Advocate (2004) SCCR 1

United States $v$ Walter (1923) 263 U S 15

Wartelle v Women's \& Children's Hosp, Inc [La 1997]704 So 2d 778 